\title{
The Problem And Threat In The Management Of Tourism Sustainability In Phuket
}

Thongphon Promsaka Na Sakolnakorn, Prince of Songkla University, Thailand Aree Naipinit, Khon Kaen University, Thailand

\begin{abstract}
This article presents a problem and threat in the management of tourism sustainability on Phuket Island. The study collected its data from in-depth interviews of 15 persons in three groups: 1) travelers, 2) residents, and 3) entrepreneurs. In addition, the research revealed seven factors that affect the management of tourism sustainability: 1) natural resources protection, 2) traffic jams, 3) tax policies, 4) cost of travel, 5) labor, 6) waste management, and 7) crime.
\end{abstract}

Keywords: Problem and Threat; Tourism; Sustainability; Management

\section{INTRODUCTION}

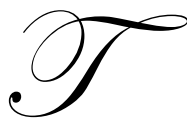

ourism involves all activities that are conducted away from home (Kelly, 1986) and it is a core business in many countries. In developing countries, particularly, tourism is important for development because it enhances economic growth and encourages local development by increasing employment and national income (Szivas, Riey, and Airey, 2003). Poirier (1995) suggested that tourism is the second most important business in the world. Global tourism revenues per year comprise approximately $25 \%$ of the world's income and they grow by $7.1 \%$ per year. Hence, if a country can design its public policy (including factors such as infrastructure, the tax system, and environmental protection) to support tourism, then the country's economic growth will increase, providing employment for local residents and increasing revenue for both local and central governments. If the country establishes a successful management plan, then this beneficial system will be sustainable (Hall, 2000).

In Thailand, tourism is essential to the country's revenue, largely because tourism attracts foreign income more than other industry sectors. The Thai tourism sector is significant within the country's economic structure for three additional reasons: 1) Tourism increases Thailand's revenue intake; 2) Tourism increases employment, raises local incomes, improves local economic structures, and stimulates the production of local goods that are related to tourism; 3) Tourism can aid social development; for example, by reducing the migration of workers toward the central region, and it encourages local people to use local resources for producing souvenirs (Ministry of Tourism and Sport, 2010).

Phuket is a popular destination for travelers from around the world. The biggest island in Thailand, Phuket, is located in the Andaman Sea in the southern area of the country. The island is mostly mountainous; in particular, a range on the west of the island stretches from the north to the south. Phuket's total area (including the province's other islands) equals approximately 570 square kilometers. The province sits approximately 536 miles (862 kilometers) south of Bangkok. In July 2005, Kratz (2005) noted that the acclaimed Fortune Magazine voted Phuket as one of the world's Top five retirement destinations.

The Phuket provincial administrative office (2009) established policies and development strategies (years 2009-2012) for encouraging tourism. The province began by supporting the central government's tourism plan. Next, Phuket endeavored to increase the value of its tourism industry by becoming an international center for 
medical services, health services, spa services, shopping, and food festivals. The provincial government also focused on developing Phuket's ecotourism, historic tourism, and environmental protections. Lastly, Phuket worked on making tourism service standard to entrepreneur and supporting community enterprises that produced goods and sold them to travelers.

After studying the primary problems that threaten tourism business management in the Phuket province, Wongsatayanon (2009) submitted eight conclusions: 1) The politicians in Phuket lack morals and ethics; 2) The local government lacks concern about local participation; 3) Traffic jams and accidents are common; 4) There is not enough water supply and the water supply system cannot support people in Phuket Island when travelers come to stay; 5) The area struggles with problems related to health, waste water, and trash; 6) The area has problems with its environment and other natural issues; 7) The area has begun to lose its local culture; and 8) Local competition to foreign investment.

This research study surveyed the problems that threaten tourism in Phuket, and the results of this study can provide a conceptual framework that policymakers can use to develop new policies that will encourage tourism sustainability in Phuket province.

\section{METHODOLOGY}

The objective of this study is to analyze the threats to tourism in Phuket province. The study used in-depth interviews of 15 persons between 26 and 30 September, 2010. The interviewees were divided into three groups: 1) travelers, 2) residents, and 3) entrepreneurs. Next, we used content analysis to evaluate the data. Subjects of the Indepth Interviews were:

$\begin{array}{ll}\text { 1. } & \text { Rongruet Chaihanam } \\ \text { 2. } & \text { Kritayut Pibool } \\ \text { 3. } & \text { Natthaphat Phendee } \\ \text { 4. } & \text { Tanaphan Naipinit } \\ \text { 5. } & \text { Suthep Tipthara } \\ \text { 6. } & \text { Kaweepoj Mutchakit } \\ \text { 7. } & \text { Kasem Joinchum } \\ \text { 8. } & \text { Sirisart Namwongsa } \\ \text { 9. } & \text { Suchart Chuchit } \\ \text { 10. } & \text { Thanita Kanok Vanichakul } \\ \text { 11. } & \text { Roongkarn Chanthasing } \\ \text { 12. } & \text { Noppadol Chantanu } \\ \text { 13. } & \text { Sutti Suwachart } \\ \text { 14. } & \text { Prapit Noopet } \\ \text { 15. } & \text { Kamphol Lortrakanon }\end{array}$

\section{RESULTS}

The in-depth interviews investigated three population groups:

\section{Travelers}

The first traveler came from the Hat-Yai district, Songkhla province, Thailand. He identified several common problems: 1) Traffic jams occur frequently in Phuket, especially during prime time (7.30 - 9.00 a.m. and 3.30 - 6.00 p.m.); 2) Food, accommodations, and public transportation have high costs, which makes travel difficult; and 3) Waste management is insufficient; some places are dirty and smelly.

The second traveler, who had moved from Khon Kaen province with her family, described four problems that threaten tourism in Phuket: 1) She feared robberies, especially at nighttime; 2) Travel is expensive; 3) Traffic 
jams are frequent; and 4) Too many sellers compete to sell their products on the beach, especially at Patong beach, which bored her family.

The third tourist was a 40-year-old man from Bangkok who came to vacation in Phuket for four days with his friend. While vacationing, he faced three main problems that hindered his enjoyment of Phuket: 1) traffic jams; 2) expensive costs for food, transportation, and accommodations; and 3) the destruction of natural resources, which were then replaced by resorts and hotels.

The fourth traveler was a 34 year-old lady from Phetchabun province. She came to Phuket with her friends and they noticed several problems that plagued Phuket tourism: 1) Traveling around Phuket is difficult because public transportation is insufficient and poor quality. 2) Some beaches in Phuket are dirty; and 3) Accommodations are expensive.

The fifth tourist came from Prachupkirikhan; he had driven to Phuket, by himself, from his home town. In Phuket, he faced five problems that hindered his travel: 1) Living costs, such as the costs of food and accommodations, are high; 2) Traffic jams occur frequently, especially downtown; 3) The town offers only a few activities and nothing new has been added for many years; 4) The town contains too many souvenir sellers and service workers (e.g., Thai masseuses and food sellers) at the beach; they follow travelers closely and continually ask them to buy their products. This makes the beach a boring place for travelers; and 5) Some places are dirty and smelly.

\section{Residents}

The first resident interviewed was a 30-year old man who worked as a government officer in Phuket. He described the following tourism problems and threats in Phuket: 1) Public transportation is inconvenient, lowquality, and expensive; 2) Too many people migrate to live in Phuket but do not register with the government database. This affects both the local and central governments, making it impossible for them to create the right policies and form accurate budgets for their administration; and 3) The natural environment is deteriorating.

The second resident identified three problems in Phuket tourism: 1) Robberies and crimes are increasing; 2) The cost of living is expensive; and 3) Many people sell items at stalls, booths, and stands, both on the beach and downtown. They present their wares directly to the travelers, which bores them and ruins their views.

The third resident had lived in Phuket for more than 10 years and he worked as a government officer in a local administration organization. He explained five problems common on Phuket Island: 1) Natural resources, especially the forests in the national park, are destroyed by humans because capitalists want to construct resorts and hotels illegally; 2) Many people commute to work. Combined with the travelers, they cause frequent traffic jams in downtown Phuket and the surrounding area; 3) Robberies and other crimes are increasing; 4) It is difficult to employ Thai labor; and 5) Waste management is insufficient, which plagues the residents with terrible smells, dirty streets, and ill health.

The fourth resident, who worked as a government officer, explained that 1) social and political conflicts make travelers afraid to travel to Thailand and Phuket; 2) the area's natural resources and forests are being destroyed, which dissatisfies the travelers; and 3) no new opportunities for entertainment or recreation have been created within the town; options are limited to activities that have been available for many years.

The fifth resident had worked and lived in Phuket for more than 15 years. He stated that 1) Phuket has many traffic jams during prime time (in the morning and after school); 2) citizens of Myanmar come to Phuket to work as laborers and the residents fear that they are increasing criminal activity; and 3) natural resources are destroyed illegally by capitalists and politicians who want to construct resorts and hotels. 


\section{Entrepreneurs}

The first entrepreneur, the owner of a service apartment downtown in the heart of Phuket, stated two problems in Phuket have been hurting his business: 1) Taxes are too high because both the local and central governments require tax payments from entrepreneurs. He had agreed to pay the local tax, but he refused to pay taxes to the Ministry of Finance's Revenue Department and 2) It is difficult to employ Thai laborers, so most entrepreneurs in Phuket employ workers from the Union of Myanmar.

The second businessman was the owner of a souvenir shop. He explained his main problems are that travelers do not spend enough money on products that are handmade by workers from the local community and that it is difficult to find Thai laborers because they do not want to work difficult jobs. Consequently, entrepreneurs in Phuket must employ laborers from Myanmar.

The third entrepreneur, a resort manager, suggested that six problems hurt her business in Phuket: 1) Phuket experiences a high rate of travelers in the popular season, but a low rate in the off season; this significant fluctuation makes it difficult to manage a business; 2) Travelers' behaviors are changing and foreigners now prefer to stay in three-star hotels rather than five-star accommodations. Further, they spend only a short amount of time in Phuket and then move on to Phang-nga or Krabi; 3) There are many competitors in the same area of business; 4) Costs are too high; 5) Financial support is lacking and loans are difficult to obtain; and 6) Businesses must pay numerous taxes, such as the local tax and the central government tax to the Revenue Department. Because of these high costs and taxes, it is difficult to operate a profitable business.

The fourth entrepreneur worked in the car rental business and he faced four problems: 1) It is difficult to borrow money from financial institutions; 2) After the economic crisis in 2009 and 2010, the number of people who travel to Phuket each year has decreased, which negatively affects the car rental industry; 3) The number of criminals in the area has increased since many people are migrating from other countries; and 4) Phuket faces problems with traffic jams, which affects both travelers and residents.

The fifth businessman moved to Phket more than 30 years ago and managed small enterprises that sold furniture and souvenirs. He stated: 1) Natural resources and forests are being destroyed and the island has changed significantly over the past few decades; 2) Travel costs, such as for hotels and food, have increased, which harms local travelers (i.e., Thai people); 3) Traffic jams occur regularly; and 4) Both local and central governments require entrepreneurs to pay hefty taxes, which overburdens the businessmen in Phuket.

\section{PROBLEM AND THREAT ANALYSIS}

Through analyzing the in-depth interviews, the author has identified the primary problems that pose obstacles to Phuket's tourism industry. These problems can be divided into three groups.

\section{Problems for Travelers}

First, traffic jams hinder everyone who stays in Phuket, especially before and after work and school. Public transportation is insufficient and hence does not offer a viable alternative. Second, the costs of travel, such as the costs of food and accommodations, are higher in Phuket than in other regions. Third, Phuket Island has lost the beauty of its natural scenery, which has been destroyed and replaced by resorts and hotels. Fourth, many places (such as the beach) are dirty and full of sellers, which makes them unappealing.

\section{Problems for Residents}

First, the natural resources and forests have been destroyed and replaced with hotels, resorts, and outdoor activities. Even the national park is disappearing. Second, traffic jams inconvenience all people in Phuket, both travelers and residents alike. Third, the cost of living in Phuket is high compared to other cities, which poses an obstacle to visitors who have limited money. Fourth, criminal activity has been increasing. 


\section{Problems for Entrepreneurs}

First, numerous and excessive taxes pose a significant problem for entrepreneurs in Phuket, making it difficult to operate a business profitably. Second, finding good workers is difficult; more than $70 \%$ of entrepreneurs employ laborers from Myanmar. Third, public transportation options, such as the bus system, are ineffective and hence do not support tourism. Downtown Phuket and other tourist areas are frequently clogged by traffic jams. Fourth, natural resources and forests are overtaken by building developments. Some capitalists even destroy the province's scenery illegally, and sometimes even in the national park. Phuket's natural beauty is being replaced by hotels, resorts, spas, and other businesses that cater to tourists.

\section{CONCLUSIONS}

This article surveyed the problems that threaten the tourism industry on Phuket Island. In addition, the research revealed seven factors that affect the management of tourism sustainability: 1) natural resources protection, 2) traffic jams, 3) tax policies, 4) cost of travel, 5) labor, 6) waste management, and 7) crime. Next, based on the study's conclusions, the article provided recommendations for the government to consider when crafting public policies to support tourism in Phuket.

In order to solidify the data and ensure that the best policies are recommended, this research must extend to interviewing more people. A quantitative method should be applied, using a questionnaire to confirm and expand the data. Accurate information will help the government design the best policies to support tourism in Phuket.

\section{AUTHOR INFORMATION}

Dr. Thongphon Promsaka Na Sakolnakorn is a lecturer at the Prince of Songkla University, Thailand. He received his first Ph.D. in development science from Khon Kaen University, Thailand, and his second doctoral degree in Ancient Indian and Asian studies from Magadh University, India. He specializes in outsourcing management, organization development, and SME management.

Dr. Aree Naipinit is an assistant professor at the Department of Management of the Faculty of Management Science, Khon Kaen University, Thailand. She received her Ph.D. in Public Administration from Magadh University, India. She specializes in SME management and strategic management.

\section{REFERENCES}

1. Hall, C.M. 2000. Tourism planning: Policies, Processes and Relationships. U.S.A: Harlow, Prentice Hall.

2. Kelly, William W. 1986. Rationalization and nostalgia: cultural dynamics of new middle-class Japan. American Ethnologist, 13(4), 603-618.

3. Kratz, E.F. 2005. Paradise Found: Where to Retire Abroad. Retrieved on October 10, 2010, from http://money.cnn.com/magazines/fortune/fortune archive/2005/07/11/8265242/index.htm.

4. Ministry of Tourism and Sport. 2010. Tourism Situation. Retrieved on March 5, 2010, from http://www.thaipr.net/nc/readnews.aspx?newsid=80D3D32E49E67EE6A4AA201BE9ABBEE7\&query=ou nNwdnFt9KnyrbUtdQ $=$.

5. Phuket provincial administrative office. 2009. Development Strategy. Retrieved on October 10, 2010, from http://www.phuketcity.org/phuketcity en/development.php.

6. $\quad$ Poirier, R.A. 1995. Tourism and development in Tunisia. Annals of Tourism Research, 22 (1), 157-171.

7. Szivas, E., Riley, M. and Airey, D. 2003. Labor mobility into tourism: attraction and Satisfaction. Annals of Tourism Research, 30 (1), 64-76.

8. Wongsatayanon, C. 2009. Phuket Tourism. Retrieved on March 5, 2010, from http://www.phuketdata.net/main/index.php?option=com_content\&task=view\&id=418\&Itemid=2. 


\section{NOTES}

